Historic, Archive Document

Do not assume content reflects current scientific knowledge, policies, or practices. 



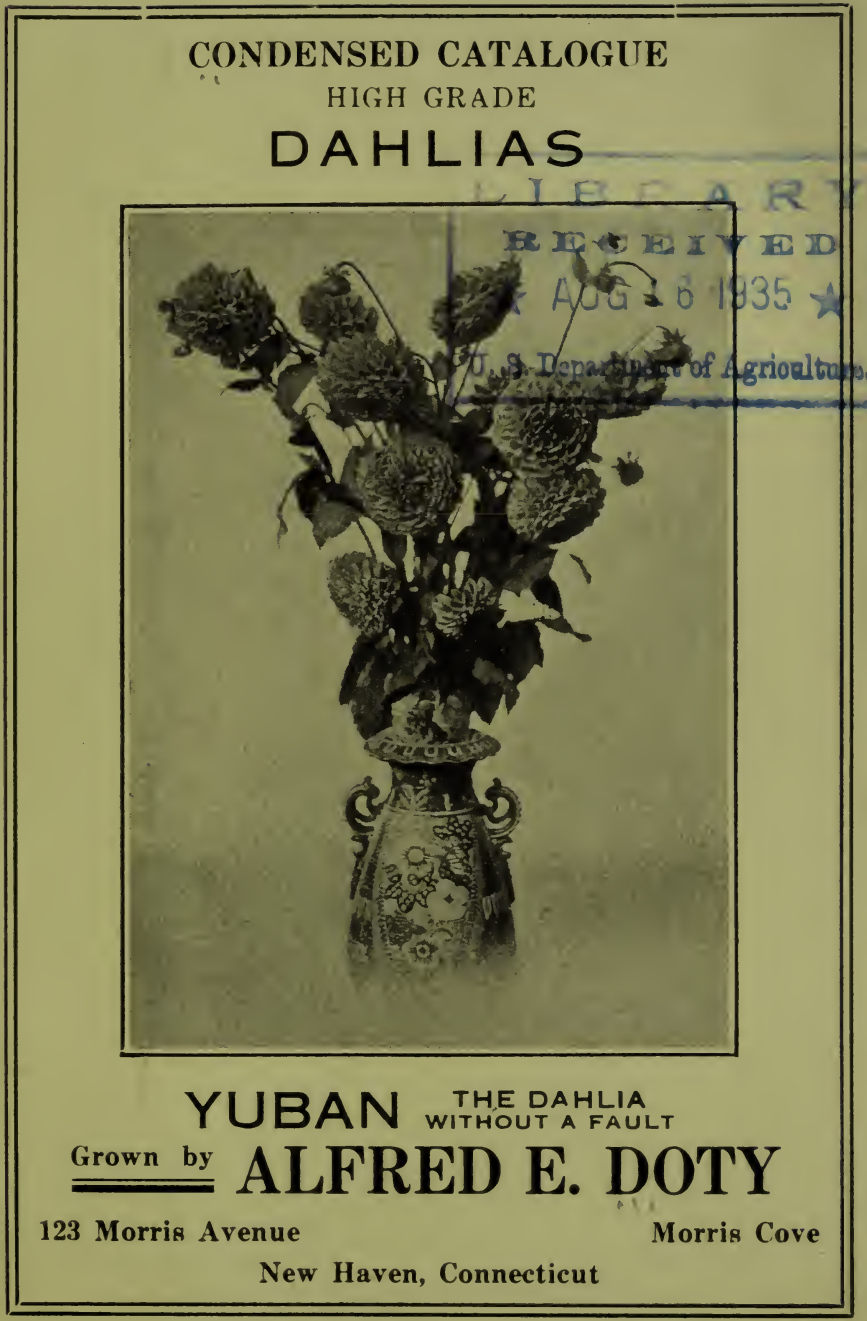

A Cannelli Calendar Printing Co. - New Haven, Conn. 


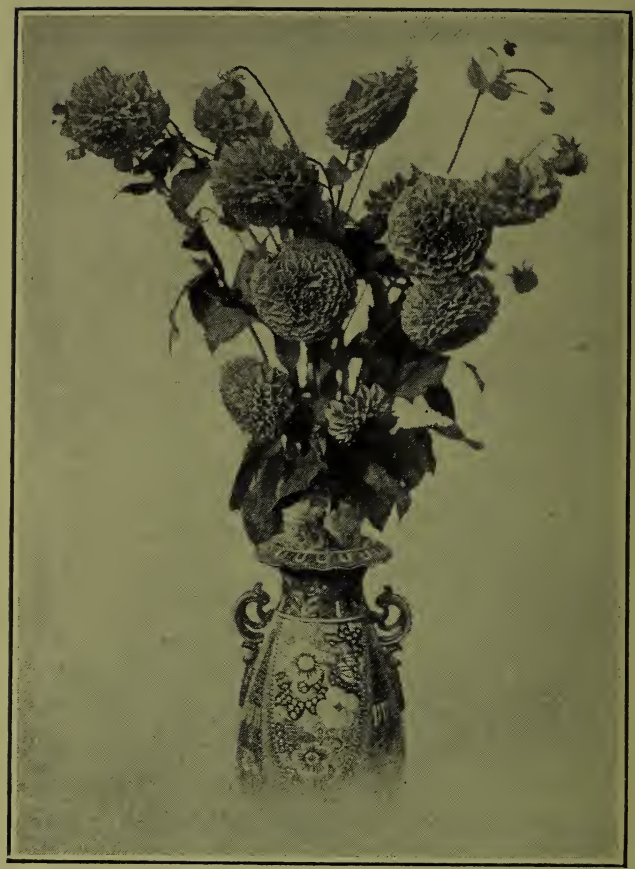

YUBAN. THE DAHLIA WITHOUT A FAULT

In this Dahlia we have the largest, free-flowering and most attractive show Dahlia grown. A very strong, robust plant, carrying its flowers on strong, stiff stems, well above the dark green foliage. Color, a golden yellow with e distinct red stripe through each petal. A prize winner wherever shown.

The price (which is in reach of ail) 


\section{To My Friends of 1920:-}

In compiling this catalogue, it gives me great pleasure to thank my many friends for the liberal patronage and recommendations given me during the pastyear, which has been the most succesful season I have had in growing the Dahlia.

It is very evident that the Dahlia loving people are appreciating the fast strides that are being made in this beautiful flower, for there has never been such a demand for the new and better varieties than now.

To be a successful grower, one must keep in touch with the different growers and exhibitions in order to secure the best the market affords.

It requires no more space or attention to grow a good Dahlia than a poor one. Why not grow the best?

In this booklet you will notice I have omitted many of the glowing descriptions which I believe are misleading and confusing, and can serve to no good purpose.

Again I call your attention to the growing of the Seedling, which is very interesting and fascinating.

I take pains to select seeds from the best of my Dahlias. This enables me to offer Dahlia seeds that will give the best results.

Visitors are always welcome to my Dahlia garden, especially in blooming time when they can make their selection from the flowering plant and get better ideas than from a catalogue.

I am always willing to impart any knowledge I may possess to aid you in growing this beautiful flower. 


\section{THE CACTUS DAHLIA.}

Distinguished by its long, twisted or pointed petals, which are often incurved, resembling the Chrysanthemums. The most popular type of the day.

\section{Alabaster}

A. R. Perry

Basilisk

Betty Bixby

Border King

Charles Craske

Conquest

Countess of Kenmare

Cygnet

Crystal

Dreadnaught

Dr. G. G. Grey

Elsie Burnel

Emblem

Empress

Falcon

Fascination

F. W. Fellows

-

Frances Graham English, old gold, shading to deep salmon rose

English varieties, pure white, very large

English, large full flower,

old rose, tipped gold

English, orange scarlet

.50

Soft Yellow, suffused bronze.

Back of petals red, full center

.75

English, scarlet, long

twisted florets, very free

.75

English, mauve Pink

.50

Deep crimson maroon, very large .35

Rich amber pink

.25

English, pale yellow, striped

carmine, free

English, silver pink good

Glowing crimson, deep-

ening to maroon

.35

Crimson scarlet

Slocombe, deep, rich velvety

crimson, very free

.75

Deep primrose, tipped rose pink, large

English, deep rose, immense

flower

English, clear yellow, shading to reddish brown

White center, deepening to pink, very large

3 English, brilliant scarlet,

long stem, good

Frederick Wenham Fawn pink, salmon center

Guardian

English, a very large Crimson

Searlet on good stem

1.00

Gen. Smith Dorrien English, fiery scarlet, very good 


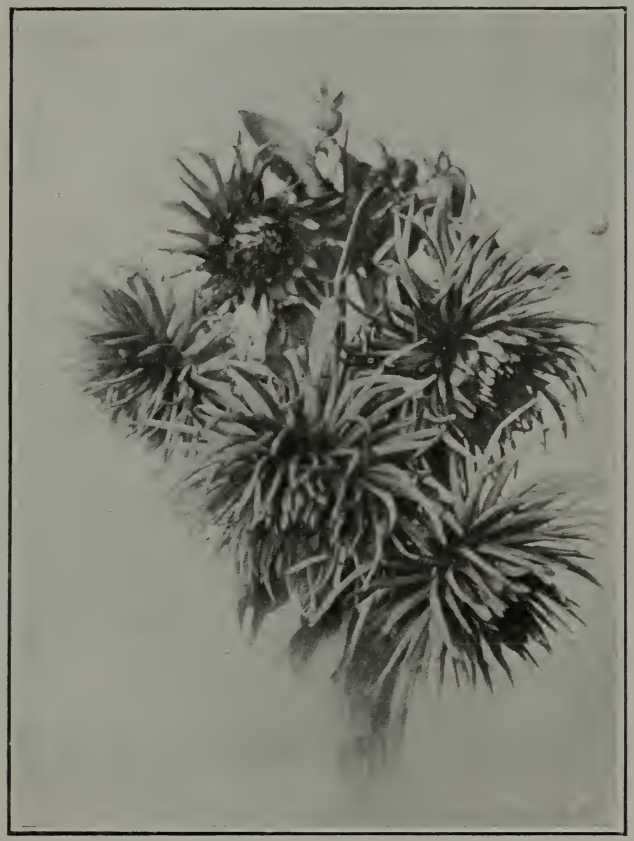

F. W. FELLOWES.

Without a doubt, the largest Cactus Dahlia grown. Brilliant orange scarlet with long straight petals. Good stem, good center and a very free bloomer Price .50 
George Walters California hybrid, one of the largest and best introduced.

Salmon pink, shading to yellow $\quad .75$

Herbert Raby English, crimson, very large, incurved type

Honesty English, pink, center white, good stem

Irene Satis

Johanesburg

John Riding

Kalif

Lorna Doone

Magnificent

Marg. Bouchon

Melody

Milton Howard

Mrs. C. Cooper

English, amber, deepening to bronze, large and full

Bright gold, very large and free $\quad .35$ English, deep rich crimson, great bloomer

Hybrid cactus, immense flower of pure scarlet

English, yellow, shading to pink, very large

English, deep orange, long straight florets

English, clear yellow and pure white

Handsume shade of pink

Mrs. Douglas Fleming English, pure white, very narrow petals

Mrs. Richard Lorhman California hybrid cactus, a pure golden yellow, immense flower on good stems

Mrs. E. W. Estes California Hybrid Cactus.

The largest and Best White

Dahlia that I have seen with a good stem

Nibelungenhort Beautiful shade of old rose, very large

Neptune

English, deep rose, striped crimson

English, soft pink with

a yellow base, good

Patriot

English, fine scarlet, incurved, large 


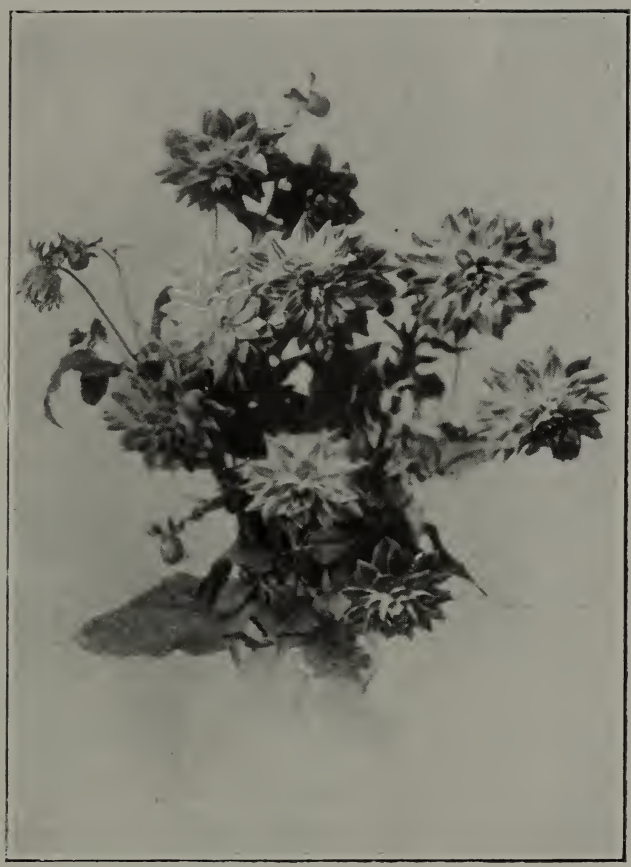

\section{LOUVINHELRICH}

A Dahlia of the Decorative variety, very strong, bold and upright, with a beautiful light green foliage.

Color is very striking and attractive, center white, with each petal striped deep red, making it as odd as its name, which name is formed by the first syllable from my four children's surnames-Louis, Vincent, Helen, Richard. Price 50 cents. 
Pierrot

French, deep amber, white

tips, very striking

Pride of Edgewood Dark rich red, good stem, very free

Record English, yellow center, passing to deep orange

Red Admiral Scarlet, very large $\quad .25$

Rev. T.W. Jamison Yellow, shade to rose $\quad .25$

R'ieinisher Froshiun White, changing to carmine rose

Rupert

English, yellow, suffused apricot, good

Ruth Gleadell California hybrid cactus, soft yellow shading to pink

Safiron

English, clear yellow, one of the best

Salome Jane Californa hybrid cactus, old gold tinged with red, immense flower $\quad .75$

San Francisco California hybrid cactus, reddish bronze

Snow Queen English, beautiful white, very fine

Southern Belle Dark maroon $\quad .50$

Success

Clear yellow, good

Sweetbriar

Beautiful pink, good stem

The Imp

English, darkest dahlia known

The Swan

English, pure white

Tom Lundy

California, immense full flower, dark rich crimson

Unique

Rich, deep red, tipped white

Valient

English, crimson scarlet, very large and full

Washington

English, crimson, free flowering 1.00

Wodan

Orange bronze and scarlet

Yellow King

Holland, this is the bestyellow

hybrid cactus grown 


\section{THE DECORATIVE DAHLIA}

This type has broad, flat petals, intermediate between the Cactus and Show types. The largest varieties are of this class.

Abundance

Aida

Albert Manda

Amphion

Azalea

Copper

Corrie

Cream King

Edna Story

D. M. Moore

Faturity

Fireburst

Flamingo

Francis Butts

Glory of New Haven
Slocombe, combination of yellow and red

California, large dark maroon $\quad .50$

Lemon, shaded pink and white $\quad .75$

English, pink suffused heliotrope, good

California, soft creamy yellow, tinged red

California, large copper flower shaded to bronze

English, heliotrope, suffused pink.75

English, primrose and cream, one of the best

An ideal cut flower. White with pink shading. A very profuse bloomer and good stem

Deep crimson maroon, almost black

English, deep old rose, very large .75

Intense scarlet, shaded orange .35

Rich, glowing rose pink $\quad .35$

Flesh white edges lavender $\quad .50$

Slocombe's Masterpiece, rich

clear lavender pink with a golden sheen

Herbert Slocombe Golden yellow, splashed red, free flower

Hortulanus Fiet Beautiful salmon yellow, large and free

Isabel Roberts

Slocombe, a large flower of an intense Velvety Red, with a good stem and very free

Jane Selby

California, a delicate mauve

Pink ố great substance.

Good stem 
Jennie Charmet Pink, shaded to rose

J. K. Alexander Rich violet purple $\quad .50$

S. Oleslagers English, well formed, large yellow flower

King of the Autumn Holland, buff yellow. Terra cotta yellow

Lady Helen

Stillman, a distinctly new and

pleasing Dahlia. Color, a

beautiful toned Pink with slight

veins of White almost Cream

running through each petal.

Extra good stem

Lee Grand Maistou White, spotted and striped violet red

Louvinhelrick Center white, striped deep red $\quad .50$

Loveliness

A very pleasing shade of pink $\quad .50$

Mabel

English, light mauve

Madona

Holland, a pure White with good stem

Marjorie Fields This is one of the best that has been introduced. A beautiful shade of pink with extra long stem

Mina Burgle California, large rich dark scarlet .35

Minute Man California, deep orange and yellow, white tips

Mildred Slocombe Delicate mauve, with a golden sheen

Mrs. Addison Pratt Slocombe, delicate buff, suffused with bronze

Mrs. Albert Lemme California, large dark velvety red

Mrs. A. J. Du Pont Bright red $\quad .75$

M:s.J. Gardner Gassett True pink, free bloomer $\quad .50$

Mrs.J.L.Emerson Slocombe, well formed flower. A warm shade of Red and Gold. Petals edged and striped gold

Mrs.Lillie P. Hathaway Formation like Yellow Collosse, of a good bright Orange

Mons. Lenormand French, bright yellow, striped red, very often comes solid color $\quad .50$ 


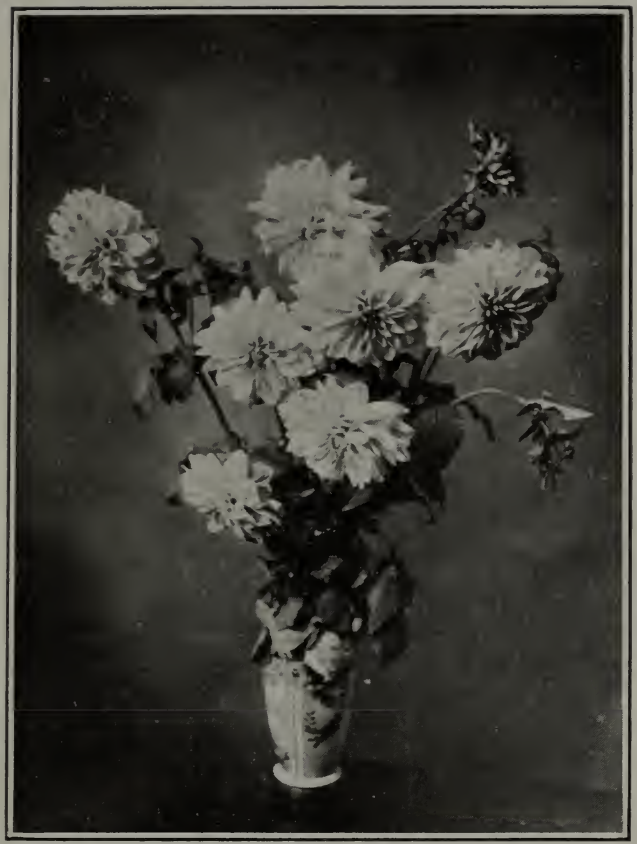

RICHARD DOTY

A decorative Dahlia, a distinct novelty in itself, and far different from anything yet introduced.

A very profuse bloomer with a mass of flowers always in bloom.

The color is lemon yellow, tipped and splashed red in so many different combinations that no two flowers are alike.

A beautiful and attractive flower in every way. Price 50 cents. 
New Haven

ᄂ Artrude

Slocombe, very bright red

California, pale lavender,

extra large

Pacific

California, cream shading to pink .75

Purity

Slocombe, the best white, always the same

Purple Manitou Dark purple

Prideof California The best decorative Dahlia that

I had the pleasure of growing.

Clear crimson red, with a full

center a shade darker

Richard Doty

Lemon yellow, tipped and splashed red

Sulphuria

English, large clear yellow, twisted petals

Sunbeam

Slocombe, bright red, faintly striped gold

St. George

English, salmon tipped white

Tenor Alveriz

Bronzed red, splashed brown

The Millionaire Stillman. This large and beautiful

Dahlia is a wonder without question. In a vase of eighteen blooms at the New Haven County Horticultural Exhibition I won first prize and a special for the best vase in the show. Color, a beautiful shade of Lavender with a Pink cast. Very full and deep with a good stem

\section{THE PEONY FLOWERED DAHLIA}

A semi-double type, has two or more rows of broad, loosely arranged petals, often pointed and sometimes twisted. Flowers of immense size and great beauty.

Amber Queen

Anna Slocombe

Attraction
A mber shaded orange, good stem .25

Soft yellow, suffused bronze, back of petals red .50

Holland, clear lilac rose, very good 
Burkley

Bertha Von Suttner

Dr. Kuyper

Dr. Perry

Elsa
Colifornia, clear golden yellow

Salmon, shaded yellow

Pure orange, large flower

Dark, reddish mahogony

California, fluffy white, one of the best

.50

.50

Rich fiery Scarlet with a good stem

Scarlet and gold, most popular of its class

Glory of Nijkirk Deep royal purple, a new shade $\quad .50$

Hampton Court Pure rich pink

.25

Yellow and scarlet

.35

A large cardinal flower

.50

Leo XIII

Liberty

Holland, a large beautiful

Yellow. Excellent stem and very free

Scarlet

Holland, purple, lined crimson one of the best

Holland, large clear yellow, good stem

Bright rich crimson

.35

English, pink suffused salmon

.35

M. McLaren

California, large salmon rose

1.00

Mrs. Warnaar

Holland, one of the best. Color Creamy White with Pink shading. Sometimes comes full

Nora Lindsay

English, buff, suffused with pink and mauve

English, pure rose, very large $\quad .75$

Paul Kruger

Striped white and red

Pure white and waxy

English, soft pink, fine form 
Sheila

South Pole

Tango

Toreador

Topsy

The Mahdi

Turner

Van Dyke

Weber
English, bright pink suffused rose

White, very large

California, a very large salmon flower

English, a very fine scarlet

A very large and striking

Mahogany Red

Terra cotta, red and white

English, a lovely shade of salmon pink

California, salmon, shaded heliotrope

A lovely shade of rose pink

\section{THE SHOW DAHLIA}

Globular in form, with petals cupped or quilled. This is probably the oldest type of dahlia and therefore more generally known.

Alice Emily

Soft yellow

Arthur Rawling Rich crimson

Autumn Belle Combination of violet, buff and cream

Big-Ben

A seedling from Yuban.

Cherry red, a monster

Bride Rose, changing to lavender

Black Diamond

California, deep maroon, almost black

Chieftain

English, purplish lilac, large

Dandy

English,orange, speckled crimson .25

David Warfield

Beautiful, deep cherry red

Dr. Keynes

Buff, shaded red, one of the best .50

Ed. Mawley

Deep crimsnn, fine petals

Emily

White tipped lavender

Erick Fisher

Buff, very fine quilled

Gen. Miles

Violet, splashed magenta

Glory of Paris

Rich purple, good stem

Gold Medal

Canary yellow, tipped white

Golden West

Light yellow, split petals

Grand Duchess Marie Buff and orange, very large 
Gracchus

Bright orange and buff

Harrison Weir Primose yellow

Harry Keith

Rosy purple

Iavanhoe

Snow white, edged lavender

John Walker

Best White

Merlin

Orange scarlet

Mad. A. Mareau The best pink grown

Mad. Hein Fatado A good white

Mrs. Susan Wilson Deep Burnt orange, veigned orange red

Murial

A charming shade of orange

Norma

Bright orange

Nugget

Orange, tipped scarlet

Perfection

Buff, shaded orange

Purple Duke

Rich deep purple

Rev. J. B. M. Camm Yellow, flaked scarlet $\quad .25$

Robert Lynn

White splashed cherry red

R. T. Rawlings The best yellow .25

Salmon Queen Salmon pink, very free $\quad .25$

Tom Jones

Cream yellow

Victory

(Kaiser Wilhelm) Deep

Yellow, tipped cherry red

Vivian

Rose pink, edged violet blue

W. W. Rawson

Pure white, overlaid amethyst

.25

Yuban

Golden yellow, splashed red

.50

\section{THE POMPON DAHLIA}

A miniature from of the Show type. Plants of dwarf growth. Profuse bloomer.
Alec
Cream, tipped pink
Arial
Buff, tinted orange
Belle of Springfield
Small light red
Bobby
Deep Plum
Clarissa
Pale primrose
Darkest of All
Blakish maroon
Dewdrop
White, with lavender edge
Dorris
A distinct shade of cream
Douglas
Dark maroon
Dr. Jim
Light ground, edged purple 
Eunice

Lavender, white shading

Girlie

Pinkish mauve

Gretchen Hein

Blush white, rose tips

Harry Snook

Clear rose pink

Irene

Rosy purple, tipped white

Johnny

Flowing maroon, crimson

Kitty Barrett

Yellow, edged red

Klein Gretchen

White, shaded crimson

Lassie

Yellow base, rose tips

Little Mary

Dark crimson

Madeline

Pale primrose and rose purple

Marguerite

Deep lilac

Nerissa

Soft rose pink

Pink Beauty

Blush pink

Snowclad

A pure white

Toni

Tommy Keith

Violet

Very fine golden yellow

\section{THE COLLARETTE DAHLIA}

Single or semi-double, with a row of peialoid stamens, usually of a contrasting color, called a collar. Fine for banquet work.

A. Nonin Brownish salmon $\quad .25$

Crown Prin :e Charlotte Chestnut red, yellow collar $\quad .25$

Dainty Soft pink, collar lemon yellow .25

Expssition De-Lyon Deep scarlet, yellow tips white collar

Giant of Lyons Deep velvet crimson, white collar very large

Grey Hound

Conbination salmon, copper

Goldstein and brown

Pure yellow, collar yellow

Henri Farman

Claret, with yellow base

Holyrood

Joe Boy

Ruby, tipped gold, collar yellow

.25

Sunset red and yellow, white collar

John Bull

Clear velvety crimson, yellow

disk collar white. Very large 
Jumbo

La Fussi

Lotus

Maurice Rivorre

Princess Louise Regularity

Scarlet Queen

Souv. De-Chabone

Volcano
Deep scarlet, collar red and yellow

Deep ox blood red, collar red and white

Almost white, lemon collar

Broad petals of maroon, collar white

Rich bright crimson, collar white .20

Purplish crimson, collar purple and white

Intense scarlet. collar golden yellow

Lemon yellow, marked coral red collar yellow and white

Crimson tipped, edged yellow collar yellow

.25

\section{CULTURAL NOTES}

Dahlias will grow and bloom in almost any kind of soil, but do not have it too rich as this will tend to foliage at the expense of blooms. More failures are caused by soil being too rich than too poor.

Plants in full sunlight and away from the roots of trees and hedges.

The size of the tuber has no effect on the size of the flowers; small tubers are as good as large ones.

Do not plant too early; from the middle of May until the middle of June is best in this latitude and good results may be had by planting as late as July first.

Always lay the tubers flat, with the sprout up, and cover with six inches of soil.

When plants are up about one foot, pinch out the center. Water freely.

Keep all dead and faded blooms picked off and do not be affraid of cutting off buds; more will come to take their place. Grow as far as possible to a single stalk, keep your ground well cultivated, and you will have plenty of flowers.

To keep cut blooms of Dahlias, burn the tips of the stems on a gas stove, or put the stems of the flowers in a pitcher containg three inches of boiling water, and leave there fifteen minutes. Remove and put the stems in a vase of fresh water containing a teaspoonful of salt to the quart. 


\section{SPECIAL OFFERS}

For the benefit of those who are not familiar with the names, color and characteristics of the Dahlia, and wish to have the selection made from them, I make the following special priced collections:

No. 1. COLLECTION-12 named varieties several classes, my ownselection, notwo alike, and each labeled.

No. 2. CoLLECTION-12 good $25 \phi$ varieties, my own selection, no two alike, and each one labeled

No. 3. Collection-12 extra fine high priced varieties, my own selection, no two alike, and each one labeled

No. 4. ColleCtion -10 of my best exhibition varieties, no two alike, and each one labeled.

No. 5. ColleCtion-20 un-named varieties, all standard goods, but labels lost in handling, a big bargain, but supply limited.

\section{RATES}

The priced named include pre-payment of postage. If wanted by express collected, estra tuhers will be added sufficient to cover express charges.

No orders sent C. O. D. Remittances need not necessarily accompany an order, but when order is packed and ready for shipment, notice will be given and upon receipt of payment same will be forwarded at once.

I guarantee all my stok sent out by me to be as represented; true to name and in strong, healthy condition.

Order early. Orders executed in strict rotation. We commence shipping about May 15th.

Sincerily yours, AI,FRED E. DOTY

Do not fail to visit our fall exhibition in September.

If you are a lover of flowers, join the New Haven County Horticultural Society 


\section{MEMORANDUM}

(MARK HERE NAMES OF FLOWERS WANTED FOR FUTUंRE REFERENCE) 


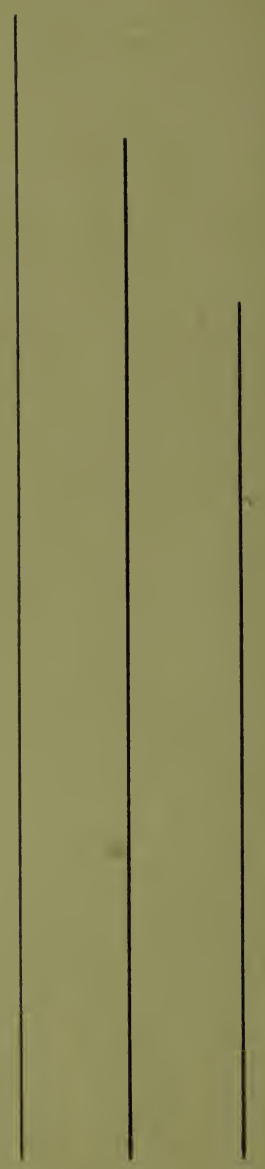

